\title{
Mobbing a odpowiedzialność cywilnoprawna
}

\author{
Mobbing and civil legal liability \\ Summary
}

The subject of this paper is the analysis of the legal liability for mobbing. The article presents remarks on the legal nature, the grounds and the scope of legal liability for mobbing. The starting point for the conducted considerations is the question whether the legal regulation contained in art. 943 of the Employment Code is of comprehensive nature. The analysis conducted in this scope allowed the determination of the role of the Civil Code regulations in claiming compensation and damages for mobbing. This paper also comments on the latest novelization of art. $94^{3} \S 4$ E. C., which was introduced into the Employment Code through the act of 16 May 2019 on alteration of act - Employment Code and some other acts (Journal of Laws 2019 item 1043). The conducted considerations became the grounds for formulating a proposal de lege ferenda.

Keywords: mobbing, compensation for mobbing, damages for mobbing, legal liability, civil legal liability, employee's personal goods.

\section{Wprowadzenie}

Złożoność zjawiska mobbingu, jego wieloaspektowy charakter, znajduje pełne odzwierciedlenie w instytucji odpowiedzialności prawnej za mobbing. Sprawcą mobbingu może być bowiem zarówno sam pracodawca, będący osobą fizyczna, jak i osoba zarządzająca zakładem pracy w imieniu pracodawcy, będącego jednostką organizacyjną, a także bezpośredni przełożony ofiary mobbingu, oraz każdy współpracownik lub podwładny. W roli mobbera mogą również występować osoby trzecie, spoza zakładu pracy, np. kontrahenci pracodawcy ${ }^{1}$, co także

1 Zob. J. Sкосzyński, D. Dzienisiuk, w: Kodeks pracy. Komentarz. Red. L. Florek. Warszawa 2017, s. 630; D. Dörre-NowaK, w: Kodeks pracy. Komentarz. Red. A. Soвczyк. Warszawa 2015, s. 448; wyrok SN z dnia 2 października 2009 r., II PK 105/09, LEX nr 794859. 
będzie obciążać pracodawcę $\mathrm{w}$ związku $\mathrm{z}$ naruszeniem przez niego obowiązku przeciwdziałania mobbingowi, nałożonego $\mathrm{w}$ art. $94^{3} \S 1$ ustawy z dnia 26 czerwca 1974 r. - Kodeks pracy². Celem niniejszego artykułu jest przyjrzenie się zagadnieniu prawnej odpowiedzialności za mobbing, szczególnie w aspekcie cywilnoprawnym, a także podjęcie próby oceny obowiązujących $\mathrm{w}$ tym obszarze regulacji prawnych i przedstawienie propozycji de lege ferenda.

\section{Podstawy i zakres odpowiedzialności prawnej za mobbing}

W kwestii podstaw oraz zakresu odpowiedzialności prawnej za mobbing nie ma jednolitego stanowiska, tak w orzecznictwie, jak i w doktrynie. Wskazać można natomiast trzy, różne od siebie, grupy poglądów: pierwszy, o całościowym uregulowaniu odpowiedzialności za mobbing w Kodeksie pracy, co wyklucza odwoływanie się do Kodeksu cywilnego ${ }^{3}$; drugi, o dopuszczalności odwoływania się - poprzez art. 300 k. p. - do uregulowań Kodeksu cywilnego w przedmiocie naruszenia dóbr osobistych, odpowiedzialności deliktowej lub kontraktowej; oraz trzeci, o dopuszczalności kumulacji obydwu tych podstaw ${ }^{4}$. Odzwierciedlenie ostatniego z przytoczonych poglądów znaleźć możemy chociażby w postanowieniu Sądu Najwyższego z dnia 9 czerwca 2010 r., w którym SN wskazał, że osoba - której dobra osobiste zostały zagrożone lub naruszone cudzym działaniem, w tym mobbingiem może dochodzić ochrony prawnej zarówno za pomocą roszczeń cywilnoprawnych jak i prawnopracowniczych, a wybór sposobu ochrony należy do poszkodowanego ${ }^{5}$.

Sąd Najwyższy niejednokrotnie zajmował również stanowisko, że odpowiedzialność z tytułu mobbingu została uregulowana w Kodeksie pracy w sposób całościowy. W wyroku z dnia 29 marca 2007 r. SN wskazał, że mobbing jest kwalifikowanym deliktem prawa pracy, a sankcje za jego stosowanie są zdarzeniami prawa pracy, które sądy

${ }^{2}$ Ustawa z dnia 26.06.1974 r. - Kodeks pracy (tekst jedn. Dz.U. z 2019 r., poz. 1040 ze zm.; dalej jako: k.p.).

${ }^{3}$ Ustawa z dnia 23.04.1964 r. - Kodeks cywilny (tekst jedn. Dz.U. z 2019 r., poz. 1145 ze zm.; dalej jako: k.c.).

${ }^{4}$ J. Sкосzyński, D. Dzienisiuk, w: Kodeks pracy. Komentarz. Red. L. Florek..., s. 634-635.

${ }^{5}$ Postanowienie SN z dnia 9.06.2010 r., II PZ 17/10, LEX nr 1086674. 
pracy osądzają przede wszystkim na podstawie art. $94^{3}$ k.p., chociaż z uwzględnieniem dorobku judykatury z zakresu orzekania o zadośćuczynieniu za doznaną krzywdę (art. 445 §1 i art. 448 k.c.) oraz kompensaty szkody wywołanej rozstrojem zdrowia (art. $444 \S 1$ k.c.) $)^{6}$.

W wyroku tym SN opowiedział się za szerokim zakresem odpowiedzialności za mobbing, wywodzonym - zdaniem sądu - wprost z art. $94^{3} \S 3$ k.p., a sprowadzającym się do zrekompensowania wydatków majątkowych w postaci kosztów koniecznego leczenia, pokrycia kosztów przekwalifikowania się do innego zawodu (w przypadku utraty zatrudnienia spowodowanej rozstrojem zdrowia), a nawet przyznania odpowiedniej renty $\mathrm{w}$ razie utraty zdolności do pracy wskutek mobbingu; ponadto naprawienia poczucia krzywdy w niematerialnej sferze psychicznej i psychologicznej osoby poszkodowanej.

W podobnym tonie wypowiedział się Sąd Najwyższy w wyroku z dnia 21 czerwca 2013 r.7. Na uwagę zasługuje również orzeczenie Sądu Najwyższego z dnia 22 stycznia 2015 r., w którym SN uznał za kontrowersyjne oparcie roszczeń odszkodowawczych, związanych $\mathrm{z}$ mobbingiem, na przepisach art. 415, 430, 471 k.c. $\mathrm{w}$ zw. z art. 300 k.p., ze względu na uregulowane roszczenie odszkodowawcze $\mathrm{z}$ tytułu mobbingu, które przysługuje tylko $\mathrm{w}$ razie rozwiązania przez pracownika umowy o pracę wskutek mobbingu (art. $94^{3}$ $\S 4$ i 5 k.p.), oraz unormowane roszczenie o zadośćuczynienie za doznaną krzywdę z rozstroju zdrowia z powodu mobbingu (art. $94^{3}$ §3 k.p.). Sąd argumentował, że: „Taka całościowa regulacja sankcji prawa pracy za stosowanie mobbingu zdaje się wykluczać (a contrario do art. 300 k.p.) dochodzenie innych niż wyraźnie uregulowane w Kodeksie pracy roszczeń [...]. Natomiast dopuszczenie dalszej lub innej odpowiedzialności odszkodowawczej na podstawie przepisów kodeksu cywilnego wymagałoby wykazania luki w prawie pracy oraz wskazania konkretnej podstawy prawnej uzupełniającej odpowiedzialności odszkodowawczej za skutki mobbingu niezaspokojone roszczeniami prawa pracy"8.

Z wyrażonym w judykaturze poglądem, który zakłada, że odpowiedzialność $\mathrm{z}$ tytułu mobbingu została uregulowana w Kodeksie

${ }^{6}$ Wyrok SN z dnia 29.03.2007 r., II PK 228/06, OSNP 2008/9-10, poz. 126.

7 III BP 4/12, źródło: Legalis (dostęp 28.06.2019 r.).

8 Wyrok SN z dnia 22.01.2015 r., III PK 65/14, źródło: Legalis (dostęp 28.06.2019 r.). 
pracy $\mathrm{w}$ sposób całościowy, trudno byłoby się zgodzić i to z kilku powodów. Po pierwsze dlatego, że $w$ art. $94^{3} \S 3$ k.p. ustawodawca zdecydował się wyłącznie na ustanowienie jednej tylko podstawy żądania przez pracownika zadośćuczynienia za mobbing, tj. podstawy $\mathrm{w}$ postaci rozstroju zdrowia, podczas gdy dóbr osobistych, jakie mogą zostać naruszone poprzez mobbing, jest więcej. W praktyce raczej rzadko będziemy mieć do czynienia z sytuacją kiedy to stosowanie wobec pracownika mobbingu doprowadzi do rozstroju zdrowia pracownika, nie powodując zarazem naruszenia jego godności oraz dobrego imienia. Są to zatem dobra osobiste pracownika, które nie powinny być uznawane za mniej istotne niż zdrowie (a przez to niezasługujące na ochronę). Godzi się podkreślić, że art. 23 k.c. zapewnia ochronę wszystkich dóbr osobistych człowieka i nie dokonuje ich wartościowania. Tymczasem ustawodawca wprowadzając do Kodeksu pracy regulację zawartą $\mathrm{w}$ art. $94^{3} \S 3$ k.p. dokonał swoistego - w mojej ocenie, nieuprawnionego - wartościowania dóbr osobistych, co niekorzystnie wpłynęło na sytuację prawną pracowników i przesądziło o braku kompleksowego uregulowania odpowiedzialności prawnej za mobbing na gruncie przepisów prawa pracy.

Jako drugi argument przemawiający za tym, że w obecnym stanie prawnym nie mamy do czynienia z całościowa, prawnopracowniczą regulacją odpowiedzialności za mobbing, należy wskazać okoliczność, że zakres uprawnień zawartych $\mathrm{w}$ art. $94^{3} \S 3$ i 4 k.p. jest ograniczony. Mianowicie, pracownik u którego mobbing wywołał rozstrój zdrowia może domagać się od pracodawcy odpowiedniej sumy pieniężnej tytułem zadośćuczynienia za doznaną krzywdę oraz - po spełnieniu przesłanek ustawowych - odszkodowania w wysokości nie niższej niż minimalne wynagrodzenie za pracę, ustalane na podstawie odrębnych przepisów. Tymczasem art. 448 k.c. stwarza możliwość domagania się przez poszkodowanego, którego dobro osobiste - nie tylko pod postacią zdrowia - zostało naruszone, zarówno odpowiedniej sumy tytułem zadośćuczynienia pieniężnego za doznaną krzywdę, jak i zasądzenia odpowiedniej sumy pieniężnej na wskazany przez poszkodowanego cel społeczny ${ }^{9}$. Natomiast $\mathrm{w}$ razie wywołania rozstroju zdrowia,

${ }_{9}$ Obecnie, zarówno w judykaturze jak i w doktrynie, zaczyna przeważać pogląd o możliwości kumulatywnego korzystania przez pokrzywdzonego z obydwu środków ochrony prawnej, przewidzianych w art. 448 k.c. Zob.: K. Mularski, w: Kodeks cywilny. 
art. 444 k.c. dodatkowo wyposaża poszkodowanego w uprawnienie do dochodzenia pokrycia wszelkich wynikłych z tego powodu kosztów. W szczególności, na żądanie poszkodowanego, zobowiązany do naprawienia szkody powinien wyłożyć z góry sumę potrzebną na koszty leczenia, a jeżeli poszkodowany stał się inwalidą, także sumę potrzebną na koszty przygotowania do innego zawodu (art. $444 \S 1$ zd. drugie k.c.). Jeśli zaś poszkodowany utracił całkowicie lub częściowo zdolność do pracy zarobkowej, albo jeżeli zwiększyły się jego potrzeby, lub zmniejszyły widoki powodzenia na przyszłość, może on żądać od zobowiązanego do naprawienia szkody odpowiedniej renty (art. $444 \S 2$ k.c.).

Kolejny argument przemawiający za twierdzeniem, że nie mamy - i w obecnie wskazywanym zakresie wręcz nie możemy mieć - do czynienia z kompleksowym uregulowaniem odpowiedzialności za mobbing w Kodeksie pracy jest taki, że odpowiedzialność z art. $94^{3}$ $\S 3$ k.p. dotyczy wyłącznie pracodawcy, a przecież pracodawca nie zawsze będzie tożsamy $z$ bezpośrednim sprawcą mobbingu. Pracownik musi zatem posiadać narzędzia prawne pozwalające mu na dochodzenie roszczeń od bezpośredniego sprawcy mobbingu, co nabiera szczególnego znaczenia, gdy bezpośrednim sprawcą mobbingu nie jest pracodawca, a wskutek mobbingu doszło do naruszenia dóbr osobistych pracownika innych niż zdrowie. Jest to istotne również w razie uchylenia się przez pracodawcę od odpowiedzialności przewidzianej w art. $94^{3} \S 3$ k.p. Kwestia możliwości uchylenia się przez pracodawcę od odpowiedzialności z art. $94^{3} \S 3$ k.p. wymaga jednak szerszych rozważań i przedstawiona zostanie w dalszej części artykułu. Obecnie jest jedynie sygnalizowana.

W świetle powyższego, w obecnym stanie prawnym należy przychylić się do poglądu, zgodnie z którym pracownik, będący ofiarą mobbingu, może wystąpić przeciwko swojemu prześladowcy - a zatem przeciwko pracodawcy, albo przeciwko innej osobie będącej bezpośrednim sprawcą mobbingu $\mathrm{w}$ miejscu pracy - również $\mathrm{z}$ roszczeniami wywodzonymi bezpośrednio z przepisów prawa cywilnego,

Tom I. Komentarz. Art. 1-44911. Red. M. Gutowski. Warszawa 2016, s. 1877; uchwała SN(7) z dnia 9.09.2008 r., III CZP 31/08, OSNC 2009, Nr 3, poz. 46; uchwała SN z dnia 19.06.2007 r., III CZP 54/07, OSNC 2008, Nr 2, poz. 36; wyrok SN z dnia 17.03.2006 r., I CSK 81/05, OSP 2007, Nr 3, poz. 30. 
czyli z klasycznymi roszczeniami cywilnoprawnymi ${ }^{10}$. Trafne stanowisko wyraził w tej materii Sąd Najwyższy, który w wyroku z dnia 2 października 2009 r., podkreślił, że „[...] zanim doszło do kodyfikacji instytucji mobbingu (wprowadzenia do Kodeksu pracy art. $94^{3}$ k.p.) w orzecznictwie przyjmowano, że ochrona pracownika przed zachowaniami pracodawcy o charakterze mobbingu może być realizowana bezpośrednio na podstawie przepisów o czynach niedozwolonych. Wprowadzenie do Kodeksu pracy przepisów o mobbingu miało zatem, między innymi, takie znaczenie, że doszło do jednoznacznego określenia odpowiedzialności pracodawcy za skutki mobbingu, a właściwie tylko za dwa spośród nich - za rozstrój zdrowia spowodowany mobbingiem i za skutki rozwiązania przez pracownika umowy o pracę $\mathrm{z}$ powodu mobbingu. Kodyfikacja instytucji mobbingu nie może jednak być traktowana jako sytuacja, w której doszło do ograniczenia - w stosunku do stanu prawnego sprzed kodyfikacji - możliwości dochodzenia przez poszkodowanego pracownika odszkodowania. Nie można przyjąć, że w obecnym stanie prawnym pracownik ma mniejsze możliwości i szanse dochodzenia od pracodawcy odszkodowania z tytułu szkody majątkowej wyrządzonej mu w wyniku stosowania mobbingu niż przed regulacją tej instytucji w Kodeksie pracy"11.

Stanowisko aprobujące cywilnoprawną podstawę roszczeń potwierdził także Sąd Najwyższy w wyroku z dnia 5 lipca 2017 r. $^{12}$. Należy zatem podzielić pogląd, w myśl którego - skoro istota mobbingu polega na naruszaniu dóbr osobistych pracownika (takich jak godność, dobre imię, zdrowie) - pracownik może skorzystać z cywilnoprawnych roszczeń służących ochronie tych dóbr. Może zatem wystąpić z roszczeniem niemajątkowym: 1) o zaniechanie naruszania dóbr osobistych pracownika $\mathrm{w}$ związku $\mathrm{z}$ mobbingiem (art. $24 \S 1$ zdanie pierwsze k.c.); 2) o dopełnienie czynności potrzebnych do usunięcia skutków naruszenia dóbr osobistych, w szczególności przez złożenie

${ }^{10}$ Wyrok SN z dnia 2.10.2009 r., II PK 105/09, źródło: Legalis. Por. także: E. Kowalska-Benasiewicz: Zadośćuczynienie za mobbing. Zbieg roszczeń. „Palestra” 1-2/2015, s. 89-97; G. JęDREJEK: Cywilnoprawna odpowiedzialność za stosowanie mobbingu. Warszawa 2004; R. PoźDzıк: Odszkodowanie, zadośćuczynienie za mobbing w miejscu pracy. Przegląd Sądowy 2004, nr 5, s. 137 i nast.; D. Dörre-NowaK: Ochrona godności i innych dóbr osobistych pracownika. Warszawa 2005, s. 261 i nast.

${ }_{11}$ Wyrok SN z dnia 2.10.2009 r., II PK 105/09, źródło: Legalis.

12 II PK 201/16, źródło: Legalis. 
oświadczenia o odpowiedniej treści i w odpowiedniej formie (art. $24 \S 1$ zdanie drugie k.c.). Pracownikowi przysługują także roszczenia majątkowe. Podstawę dochodzenia od pracodawcy roszczeń majątkowych (zadośćuczynienia, a także odszkodowania z tytułu mobbingu) stanowi w pierwszej kolejności art. $94^{3} \S 3$ i $\S 4$ k.p. Ale pracownik będący ofiarą mobbingu przed sądem pracy może dochodzić od pracodawcy również takich roszczeń, które nie mogą być zaspokojone na podstawie art. $94^{3} \S 3$ oraz $\S 4$ k.p. Chodzi tu o roszczenie o zadośćuczynienie pieniężne za krzywdę doznaną wskutek naruszenia dóbr osobistych pracownika dotkniętego mobbingiem (oczywiście chodzi o dobra osobiste inne niż zdrowie), jak również o zapłatę odpowiedniej sumy na wskazany przez pracownika cel społeczny (art. 448 k.c.). Pracownik może także na podstawie art. $24 \S 2 \mathrm{w}$ zw. z art. 415 i następne k.c., dochodzić naprawienia szkody wyrządzonej naruszeniem jego dóbr osobistych. Dostępne dla pracownika jest także roszczenie przewidziane w art. 444 k.c., czyli o naprawienie szkody majątkowej spowodowanej uszkodzeniem ciała lub wywołaniem rozstroju zdrowia (a w tym także domaganie się stosownej renty $)^{13}$. Wymienione roszczenia są oczywiście dostępne dla pracownika również w sytuacji, gdy chce on wytoczyć powództwo przeciwko bezpośredniemu sprawcy mobbingu, którym nie jest pracodawca.

\section{Charakter prawny odpowiedzialności za mobbing}

Zasygnalizowania wymaga również kwestia charakteru prawnego odpowiedzialności za mobbing, gdyż i w tym przedmiocie zdania są podzielone. Zarówno w orzecznictwie Sądu Najwyższego, jak i w literaturze, został wyrażony pogląd, że skutki prawne niewywiązania się przez pracodawcę $\mathrm{z}$ obowiązku przeciwdziałania mobbingowi należy oceniać $w$ ramach reżimu odpowiedzialności kontraktowej ${ }^{14}$. Do wniosku takiego miałaby prowadzić okoliczność, że w przypad-

13 Zob. wyrok SN z dnia 2.10.2009 r., II PK 105/09, źródło: Legalis; wyrok SN z dnia 9.03.2011 r., II PK 226/10, LEX nr 817522; M. TomaszewsKa, w: Kodeks cywilny. Komentarz. Red. K.W. Baran. Warszawa 2018, s. 707. Por. także: H. Szewczyк: Ochrona dóbr osobistych w zatrudnieniu. Warszawa 2007, s. 604 i nast.

14 Zob. np. J. SкосzyŃski, D. Dzienisiuk: Kodeks pracy. Komentarz. Red. L. Florek..., s. 634; wyrok SN z dnia 3.08.2011 r., I PK 35/11, http://www.sn.pl/sites/orzecznictwo/ orzeczenia1/i\%20pk\%2035-11-1.pdf (dostęp 1.07.2019 r.). 
ku odpowiedzialności deliktowej odszkodowanie stanowi świadczenie pierwotne, istniejące od momentu powstania zobowiązania, tj. od momentu wyrządzenia deliktu. Natomiast w odpowiedzialności kontraktowej odszkodowanie stanowi świadczenie wtórne, konsekwencję niewykonania lub nienależytego wykonania zobowiązania. W tym kontekście odszkodowanie, jak również zadośćuczynienie za mobbing, nie ma charakteru pierwotnego. W oparciu o zaprezentowane powyżej wywody, Sąd Najwyższy stwierdził, że przeciwdziałanie mobbingowi stanowi kontraktowy obowiązek pracodawcy. Jeśli zatem pracownik domaga się odpowiedzialności pracodawcy za nieprzeciwdziałanie mobbingowi, to zarzuca mu nienależyte wykonanie zobowiązania ${ }^{15}$.

$\mathrm{Z}$ przedstawionym powyżej stanowiskiem nie sposób się jednak zgodzić. Wydaje się bowiem, że niewłaściwe jest klasyfikowanie skutków prawnych niewywiązania się przez pracodawcę z obowiązku przeciwdziałania mobbingowi $\mathrm{w}$ ramach reżimu odpowiedzialności kontraktowej. W mojej ocenie, odpowiedzialność pracodawcy, niewykonującego obowiązku przeciwdziałania mobbingowi, opiera się na zasadach odpowiedzialności deliktowej. Na poparcie tej tezy w doktrynie zaprezentowano już przekonujące stanowisko, z którym wypada się zgodzić. Mianowicie, trafny jest pogląd, zgodnie z którym na podstawie art. 471 k.c. można się domagać naprawienia szkody wynikłej z naruszenia zobowiązania, którego źródłem jest umowa zobowiązaniowa. Obowiązek pracodawcy przeciwdziałania mobbingowi nie jest jednak elementem kontraktu. Obowiązek ten wynika bowiem z ogólnego nakazu prawnego, skierowanego przez ustawodawcę do każdego podmiotu zatrudniającego pracowników. To nie pracodawca zobowiązuje się wobec drugiej strony stosunku pracy do przeciwdziałania mobbingowi - to państwo nakłada na niego taki obowiązek ${ }^{16}$, wyrażony wprost $\mathrm{w}$ art. $94^{3} \S 1$ k.p. Obowiązek przeciwdziałania przez pracodawcę mobbingowi kształtowany jest zatem wolą państwa, a nie wolą stron. W gestii pracodawcy pozostaje jedynie swoboda, co do wyboru konkretnych działań, które podejmie w celu realizowania tego obowiązku. Za oparciem reguł odpowiedzialności pracodawcy, niewykonującego obowiązku przeciwdziałania mobbingowi, na zasadach

${ }^{15}$ Wyrok SN z dnia 03.08.2011 r., I PK 35/11.

16 D. Dörre-KolasA, w: Kodeks pracy. Komentarz. Red. A. SовсzYк. Warszawa 2018, s. 495-496. 
odpowiedzialności deliktowej przemawia również charakter roszczeń przysługujących pracownikowi. W literaturze podkreśla się bowiem, że zadośćuczynienie pieniężne za krzywdę oraz odszkodowanie należne (bez względu na powstanie szkody i jej wysokość) nie są znane odpowiedzialności kontraktowej ${ }^{17}$.

Dominika Dörre-Kolasa przypomina, że podstawową zasadą odpowiedzialności deliktowej jest zasada winy (art. 415 k.c.) i podkreśla, że odpowiedzialność pracodawcy za mobbing, będący skutkiem braku przeciwdziałania, będzie się opierać na zasadzie winy. A jedynie wyjątkowo na zasadzie ryzyka, przewidzianej w art. 430 k.c. Zdaniem D. Dörre-Kolasy z odpowiedzialnością opartą o zasadę ryzyka będziemy mieć do czynienia bardzo rzadko, tj. np. w sytuacji, gdy nieprzeciwdziałanie mobbingowi polegało na powierzeniu przez pracodawcę zarządzania zespołem (połączonego $\mathrm{z}$ daleko idącą swobodą w decydowaniu) osobie, co do której pracodawca miał wiedzę, że w przeszłości dopuszczała się już nękania i zastraszania innych pracowników, a z którą - ze względu na bardzo dobre wyniki finansowe, osiągane przez tę osobę - nie rozwiązano stosunku pracy, lecz osoba ta została przeniesiona na inne stanowisko, $\mathrm{w}$ innej lokalizacji ${ }^{18}$.

Z poglądem D. Dörre-Kolasy w przedmiocie odpowiedzialności pracodawcy na zasadzie ryzyka (art. 430 k.c.), która - jej zdaniem występuje jedynie w wyjątkowych przypadkach, trudno się jednak zgodzić. Przeciwnie, wydaje się, że odpowiedzialność pracodawcy, oparta na zasadzie ryzyka (art. 430 k.c.), będzie mieć miejsce stosunkowo często, tj. w tych wszystkich przypadkach, gdy sprawcą mobbingu jest przełożony ofiary mobbingu, który dopuścił się mobbingu, nadużywając swej dominującej pozycji w związku z wykonywaniem, powierzonych mu przez pracodawcę, obowiązków nadzorczych względem pracownika. Odpowiedzialność pracodawcy na zasadzie ryzyka, przewidziana $\mathrm{w}$ art. 430 k.c., będzie mieć miejsce również $\mathrm{w}$ sytuacji, gdy prześladowcą pracownika będzie nie jego przełożony lecz inny pracownik, jeżeli do mobbingu doszło w związku z mieszczącą się w zakresie obowiązków pracowniczych współpracą pomiędzy sprawcą a ofiarą mobbingu, a nie tylko przy okazji zatrudnienia u tego samego pracodawcy i wykonywania obowiązków w tym samym zakładzie

17 Ibidem, s. 496.

18 Zob. D. Dörre-Kolasa, w: Kodeks pracy. Komentarz. Red. A. Sовсzүк..., s. 496- 497. 
pracy ${ }^{19}$. Warto przypomnieć, że art. 430 k.c. przewiduje odpowiedzialność zwierzchnika za zawinione zachowanie podwładnego i jest przepisem szczególnym wobec art. 429 k.c. Zwierzchnikiem jest podmiot, na rachunek którego następuje wykonanie czynności - $\mathrm{w}$ analizowanym przypadku pracodawca. Odpowiedzialność z art. 430 k.c. została oparta na zasadzie ryzyka $\mathrm{i}$ - odmiennie od innych regulacji przewidujących odpowiedzialność obiektywną - komentowany przepis nie wskazuje na żadne okoliczności egzoneracyjne, których zaistnienie skutkowałoby uniknięciem odpowiedzialności przez podmiot powierzający wykonanie czynności podwładnemu. Z tego względu odpowiedzialność z art. 430 k.c. określana jest niekiedy mianem odpowiedzialności obiektywnej, bądź odpowiedzialności za skutek. Surową odpowiedzialność łagodzi jednak wymóg zawinionego działania wykonawcy (podwładnego) ${ }^{20}$. Natomiast odpowiedzialność pracodawcy na zasadzie winy będzie mieć miejsce $w$ przypadkach, gdy sprawcą mobbingu będzie sam pracodawca lub osoba zarządzająca zakładem pracy $\mathrm{w}$ imieniu pracodawcy, a także $\mathrm{w}$ sytuacji, gdy działania mobbingowe wprawdzie nie będą pochodzić od samego pracodawcy, lecz od osoby trzeciej, ale zarazem będzie to osoba, która nie podlega kierownictwu pracodawcy i nie ma obowiązku stosowania się do jego poleceń (np. klient pracodawcy; kontrahent pracodawcy). W odniesieniu do ostatniego z wymienionych przypadków, kiedy to sprawcą mobbingu jest osoba trzecia niebędąca podwładnym pracodawcy, a zatem osoba niepodlegająca jego kierownictwu, można podzielić stanowisko, w myśl którego - jeżeli pracodawca podjął środki z zakresu prewencji antymobbingowej (wprowadzając regulacje wewnętrzne, mające na celu zakazanie nieetycznych zachowań wobec pracowników, prowadził intensywną akcję promującą pozytywne wzorce zachowań, szkolił pracowników i uczulał na zachowania, które są nieakceptowalne), a mobbing w zakładzie pracy i tak wystąpił - to wówczas pracodawca zwolniony jest z odpowiedzialności, którą powinien ponieść wyłącznie bezpośredni sprawca mobbingu ${ }^{21}$. s. 634 .

19 Por. J. SкосzүŃski, D. Dzienisiuk: Kodeks pracy. Komentarz. Red. L. Florek...,

${ }^{20}$ M. Zelek, w: Kodeks cywilny. Tom II. Komentarz. Art. 353-626. Red. M. GutowsKI. Warszawa 2019, źródło: Legalis. Zob. także: wyrok SN z dnia 14.03.2012 r., II CSK 343/11, źródło: Legalis.

${ }^{21}$ Por. D. Dörre-Kolasa, w: Kodeks pracy. Komentarz. Red. A. Sовсzүк..., s. 496. 


\section{Nowelizacja art. $94^{3} \S 4$ k.p. - ocena zmian}

Rozważania zawarte $\mathrm{w}$ niniejszym opracowaniu z pewnością nie byłyby kompletne, gdyby nie zawierały odniesienia do najnowszej nowelizacji art. $94^{3} \S 4$ k.p., wprowadzonej ustawą z dnia 16 maja 2019 r. o zmianie ustawy Kodeks pracy oraz niektórych innych ustaw ${ }^{22}$. Zmiana dokonana $\mathrm{w}$ art. $94^{3} \S 4$ k.p. wchodzi w życie $\mathrm{z}$ dniem 7 września 2019 r. i z całą pewnością nie ma charakteru kosmetycznego. Ustawodawca zdecydował się bowiem na rozszerzenie uprawnień pracownika będącego ofiarą mobbingu - i co za tym idzie odpowiedzialności pracodawcy - $\mathrm{w}$ ten sposób, że przyznał pracownikowi, który doznał mobbingu, prawo do dochodzenia od pracodawcy odszkodowania $\mathrm{w}$ wysokości nie niższej niż minimalne wynagrodzenie za pracę, ustalane na podstawie odrębnych przepisów, niezależnie od tego, czy stosunek pracy ustał, czy trwa nadal. Należy podkreślić, że przed nowelizacją z dnia 16 maja 2019 r., przewidziane w art. $94^{3} \S 4$ k.p. uprawnienie do dochodzenia odszkodowania przysługiwało wyłącznie pracownikowi, który wskutek mobbingu rozwiązał umowę o pracę. Nowe brzmienie art. $94^{3} \S 4$ k.p., w myśl którego „Pracownik, który doznał mobbingu lub wskutek mobbingu rozwiązał umowę o pracę, ma prawo dochodzić od pracodawcy odszkodowania w wysokości nie niższej niż minimalne wynagrodzenie za pracę, ustalane na podstawie odrębnych przepisów", stanowi zatem istotne rozszerzenie uprawnień odszkodowawczych, przysługujących pracownikom, będącym ofiarami mobbingu.

W uzasadnieniu do projektu ustawy o zmianie ustawy - Kodeks pracy oraz niektórych innych ustaw ${ }^{23}$ możemy przeczytać, że dotychczasowa regulacja instytucji mobbingu nie zapewniała jednakowej ochrony wszystkim pracownikom, wobec których stosowano praktyki mobbingowe. Nie stanowiła również skutecznego instrumentu, $\mathrm{z}$ jednej strony zniechęcającego do stosowania mobbingu, a $\mathrm{z}$ drugiej strony zachęcającego pracodawcę do prowadzenia działań antymobbingowych, o których mowa $\mathrm{w}$ art. $94^{3} \S 1$ k.p. Co istotne, w uzasad-

22 Dz.U. 2019 poz. 1043. Dalej jako: nowelizacja z dnia 16 maja 2019 r.

${ }^{23}$ Uzasadnienie do przedstawionego przez Prezydenta Rzeczypospolitej Polskiej projektu ustawy o zmianie ustawy - Kodeks pracy oraz niektórych innych ustaw. Druk sejmowy nr 1653. Uzasadnienie dostępne na stronie: https://www.sejm.gov.pl/sejm8. nsf/druk.xsp?nr=1653 (dostęp 1.07.2019 r.). Dalej powoływane, jako: uzasadnienie do nowelizacji z dnia 16 maja 2019 r. 
nieniu do nowelizacji z dnia 16 maja 2019 r. zwrócono także uwagę na trzy wymiary, w których dała się zaobserwować dotychczasowa wadliwość przepisu art. $94^{3} \S 4$ k.p. Po pierwsze: bezpodstawne ograniczenie kręgu osób uprawnionych do wystąpienia z żądaniem odszkodowania tylko do tych pracowników, którzy rozwiązali stosunek pracy, oparte na błędnym założeniu, że stopień uciążliwości praktyk mobbingowych jest tak duży, że dalsze kontynuowanie zatrudnienia przez pracownika jest niemożliwe. A tymczasem praktyka sądowa pokazuje, że niejednokrotnie żądania pracowników, którzy rozwiązali stosunek pracy i wystąpili z roszczeniem o odszkodowanie okazują się niezasadne. $Z$ drugiej natomiast strony, pracownicy, którzy faktycznie padli ofiarą praktyk mobbingowych, niejednokrotnie nie decydują się na rozwiązanie stosunku pracy ze względów bytowych. W takich sytuacjach pracodawca, który dopuszczał się stosowania mobbingu, albo zezwalał na stosowanie mobbingu, pozostawał bezkarny, gdyż pracownik, który nie rozwiązał stosunku pracy nie mógł dochodzić odszkodowania. Drugi aspekt, na który zwrócono uwagę to ten, że pracownik będący ofiarą mobbingu, dotychczas nie mógł skutecznie ubiegać się o odszkodowanie wówczas, gdy jego stosunek pracy został rozwiązany przez samego pracodawcę. Wskazano, iż praktyka taka nierzadko jest stosowana przez pracodawców, którzy spodziewając się pozwu o odszkodowanie, sami wcześniej rozwiązują stosunek pracy, unikając w ten sposób odpowiedzialności odszkodowawczej. I wreszcie ostatnia kwestia, na którą zwrócono uwagę w uzasadnieniu do nowelizacji z dnia 16 maja 2019 r., to brak racjonalnego uzasadnienia dla zróżnicowania przez ustawodawcę przesłanek dochodzenia roszczeń przysługujących pracownikowi, wobec którego stosowano mobbing. Zadośćuczynienia pieniężnego za doznaną krzywdę, spowodowaną rozstrojem zdrowia, pracownik może bowiem dochodzić niezależnie od tego, czy rozwiązał umowę o pracę czy nie ${ }^{24}$.

Nowelizację art. $94^{3} \S 4$ k.p. ocenić należy pozytywnie, tj. jako krok naprzód w poszerzeniu ochrony prawnej przysługującej wszystkim pracownikom dotkniętym mobbingiem. Decyzja o rozwiązaniu stosunku pracy bądź o pozostaniu w nim, pomimo doświadczenia mobbingu, powinna bowiem należeć wyłącznie do pracownika. Dotychczasowe rozwiązanie prawne, łączące uprawnienie do dochodzenia

${ }^{24}$ Uzasadnienie do nowelizacji z dnia 16 maja 2019 r., s. 11-12. 
odszkodowania z rozwiązaniem stosunku pracy przez pracownika, nie było korzystne dla ofiar mobbingu. Niejednokrotnie w praktyce miała bowiem miejsce sytuacja, w której mobbing ustawał na skutek odejścia sprawcy mobbingu $\mathrm{z}$ zakładu pracy. W takich przypadkach ofiara mobbingu powinna mieć możliwość kontynuowania zatrudnienia - jeśli taka jest wola osoby dotkniętej mobbingiem - i dochodzenia odszkodowania od pracodawcy. Nowelizacja z dnia 16 maja 2019 r. stwarza taką możliwość.

\section{Propozycje de lege ferenda}

Regulacje Kodeksu cywilnego pełnią niezwykle istotną rolę w sferze odpowiedzialności z tytułu mobbingu i są niemożliwe do wyeliminowania, chociażby $z$ tej przyczyny, że - w niektórych stanach faktycznych i prawnych - odpowiedzialność za mobbing będzie możliwa do wyegzekwowania jedynie w płaszczyźnie cywilnoprawnej. $\mathrm{W}$ odniesieniu do zadośćuczynienia będzie to mieć miejsce w sytuacji, gdy bezpośrednim sprawcą mobbingu nie będzie pracodawca, lecz np. klient pracodawcy, a jednocześnie pracodawca uwolni się od odpowiedzialności przewidzianej w art. $94^{3} \S 3$ k.p. poprzez udowodnienie, że podjął wszelkie dostępne działania, mające na celu przeciwdziałanie mobbingowi i, oceniając te działania, obiektywnie można potwierdzić ich potencjalną skuteczność. Wówczas roszczenia z tytułu mobbingu będzie można skierować jedynie przeciwko sprawcy mobbingu, a podstawą odpowiedzialności będą wyłącznie przepisy Kodeksu cywilnego ${ }^{25}$. Podobnie sytuacja będzie się kształtowała w razie naruszenia przez sprawcę mobbingu dóbr osobistych pracownika, innych niż zdrowie.

W ramach propozycji de lege ferenda, uzasadnione wydaje się jednak zgłoszenie postulatu poszerzenia przez ustawodawcę zakresu odpowiedzialności uregulowanej $w$ art. $94^{3} \S 3$ k.p., poprzez dodanie innych jeszcze - niż rozstrój zdrowia - podstaw żądania zadośćuczynienia za mobbing. Samodzielną podstawę dochodzenia roszczenia z art. $94^{3}$ $\S 3$ k.p. mogłoby stanowić naruszenie przez mobbing dóbr osobistych pracownika, takich jak: godność osobista, dobre imię czy prawo do prywatności. Chociaż dochodzenie przez ofiarę mobbingu ochrony w/w dóbr osobistych, w aktualnym stanie prawnym, jest w pełni moż-

25 D. Dörre-Kolasa, w: Kodeks pracy. Komentarz. Red. A. SовсzYк..., s. 495. 
liwe na podstawie przepisów Kodeksu cywilnego, co zostało wcześniej omówione, to jednak wydaje się, iż poszerzenie katalogu dóbr osobistych pracownika, bezpośrednio w art. $94^{3} \S 3$ k.p., wzmocniłoby ochronę prawną pracownika, poprzez spełnianie dodatkowej funkcji prewencyjnej. Obecna regulacja prawna zawarta $w$ art. $94^{3} \S 3$ k.p. może bowiem pośrednio osłabiać czujność pracodawców w sferze przeciwdziałania mobbingowi, prowadząc do szkodliwego i błędnego wniosku, że skoro ustawodawca w art. $94^{3} \S 3$ k.p. przewidział wyłącznie jedną podstawę żądania zadośćuczynienia za mobbing, w postaci rozstroju zdrowia, to występujące $\mathrm{w}$ zakładzie pracy zjawiska godzące jedynie(!) w dobre imię pracownika, w jego godność osobista, można potraktować jako wypadki mniejszej wagi, nie stanowiące jeszcze pełnoobjawowego mobbingu.

\section{Podsumowanie}

Nowelizacja art. $94^{3} \S 4$ k.p., chociaż oceniona pozytywnie, nie zmienia jednak ogólnego obrazu, jaki wyłania się z obowiązujących obecnie regulacji prawnych, dotyczących odpowiedzialności z tytułu mobbingu. Obraz ten jest natomiast taki, że chociaż pracownicy dotknięci mobbingiem mogą dochodzić szeroko zakreślonych roszczeń na podstawie przepisów Kodeksu cywilnego, to jednak zasadne wydaje się poszerzenie i wzmocnienie odpowiedzialności za mobbing bezpośrednio na gruncie Kodeksu pracy. Nowelizacja art. $94^{3} \S 4$ k.p. pozostaje zatem niewystarczająca dla realnego poprawienia sytuacji prawnej osób zagrożonych i dotkniętych mobbingiem. Przede wszystkim zwrócić należy uwagę na okoliczność, że zakres odpowiedzialności prawnej za mobbing, przewidzianej w art. $94^{3}$ k.p., jest niewystarczający. Ochrona na podstawie Kodeksu pracy powinna być wzmocniona, chociażby poprzez - postulowane powyżej - dodanie innych jeszcze niż zdrowie dóbr osobistych pracownika, jako samodzielnych podstaw dochodzenia zadośćuczynienia pieniężnego za doznaną krzywdę. W przeciwnym razie odpowiedzialność sprawcy mobbingu może być dotknięta tendencją do rozmywania się i wywoływania błędnego wrażenia, że skoro bezpośrednio w Kodeksie pracy ustawodawca nie wyposażył pracownika $\mathrm{w}$ roszczenie o zadośćuczynienie pieniężne za doznaną krzywdę, wywołaną przez mobbing, który naruszył dobre imię pra- 
cownika, jego godność czy prawo do prywatności, to w istocie - w razie tego typu naruszeń - nie mamy jeszcze do czynienia z mobbingiem, a dokonane naruszenia mieszczą się $\mathrm{w}$ granicach bliżej nieokreślonej normy, akceptowalnej przez ustawodawcę. Ponadto, jak słusznie podkreślono w uzasadnieniu do nowelizacji z dnia 16 maja 2019 r.: „,Odpowiednim zabezpieczeniem nie jest także możliwość dochodzenia przez pracownika odszkodowania na zasadach ogólnych. Jest to nie tylko trudniejsze (wiąże się chociażby z koniecznością uiszczenia wyższej, niż w sprawach pracowniczych, opłaty sądowej), ale też nie wszyscy pracownicy wiedzą o tej możliwości (nie wynika ona z Kodeksu pracy). Ponadto, poniekąd oczywistym jest, że skoro mamy do czynienia z naruszeniem przepisów Kodeksu pracy, to materialnoprawną podstawę roszczeń pracownika $\mathrm{z}$ tego tytułu powinny stanowić przepisy tego Kodeksu, a dochodzenie tych roszczeń powinno następować w takim samym trybie, jak innych spraw z zakresu prawa pracy" ${ }^{26}$. Powyższe spostrzeżenia zachowują aktualność także $\mathrm{w}$ odniesieniu do dochodzenia przez pracownika (ofiarę mobbingu) roszczeń na podstawie Kodeksu cywilnego w przypadku, gdy na skutek mobbingu doszło do naruszenia dóbr osobistych pracownika, innych niż zdrowie. Należy zatem wyrazić ubolewanie nad tym, że ustawodawca, formułując takie tezy, nie pokusił się o głębsze refleksje na temat odpowiedzialności prawnej za mobbing na gruncie Kodeksu pracy i nie zdecydował się na dalej idącą nowelizację art. $94^{3} \mathrm{k} . \mathrm{p}$.

\section{Bibliografia}

Dörre-NowaK D.: Ochrona godności i innych dóbr osobistych pracownika. Warszawa 2005.

Dörre-NowaK D., w: Kodeks pracy. Komentarz. Red. A. SobczyK. Warszawa 2015.

Dörre-Kolasa D., w: Kodeks pracy. Komentarz. Red. A. Sobczyк. 4 wyd. Warszawa 2018.

JęDRejeK G.: Cywilnoprawna odpowiedzialność za stosowanie mobbingu. Warszawa 2004.

Kowalska-Benasiewicz E.: Zadośćuczynienie za mobbing. Zbieg roszczeń. „Palestra" $1-2 / 2015$.

${ }^{26}$ Uzasadnienie do nowelizacji z dnia 16 maja 2019 r., s. 12. 
Mularski K., w: Kodeks cywilny. Tom I. Komentarz. Art. 1 - 44911. Red. M. GuTOWsKi. Warszawa 2016.

PoźDzıк R.: Odszkodowanie, zadośćuczynienie za mobbing w miejscu pracy. „Przegląd Sądowy" 2004, nr 5.

Skoczyński J., Dzienisiuk D., w: Kodeks pracy. Komentarz. Red. L. Florek. Warszawa 2017.

Szewczyк H.: Ochrona dóbr osobistych w zatrudnieniu. Warszawa 2007.

Tomaszewska M., w: Kodeks cywilny. Komentarz. Red. K.W. Baran. Warszawa 2018.

Zelek M., w: Kodeks cywilny. Tom II. Komentarz. Art. 353-626. Red. M. GutowSKI. Warszawa 2019.

\section{Mobbing a odpowiedzialność cywilnoprawna}

Streszczenie

Przedmiotem niniejszego opracowania jest analiza prawnej odpowiedzialności za mobbing. W artykule przedstawiono uwagi na temat charakteru prawnego, podstaw oraz zakresu odpowiedzialności prawnej z tytułu mobbingu. Punktem wyjścia dla prowadzonych rozważań stało się pytanie czy regulacja prawna zawarta w art. $94^{3}$ Kodeksu pracy ma charakter całościowy. Dokonana w tym zakresie analiza pozwoliła na określenie roli przepisów Kodeksu cywilnego w dochodzeniu zadośćuczynienia oraz odszkodowania za mobbing. W opracowaniu niniejszym skomentowano również najnowszą nowelizację art. $94^{3} \S 4$ k.p., która została wprowadzona do Kodeksu pracy poprzez Ustawę z dnia 16 maja 2019 r. o zmianie ustawy Kodeks pracy oraz niektórych innych ustaw (Dz.U. 2019 poz. 1043). Przeprowadzone rozważania stały się podstawą do sformułowania propozycji de lege ferenda.

Słowa kluczowe: mobbing, zadośćuczynienie za mobbing, odszkodowanie za mobbing, odpowiedzialność prawna, odpowiedzialność cywilnoprawna, dobra osobiste pracownika

\section{Le harcèlement professionnel et la responsabilité civile et juridique}

\section{Résumé}

C'est l'analyse de la responsabilité juridique du harcèlement professionnel qui est l'objet de cet article. On y a présenté les remarques sur le caractère juridique, les fondements et l'étendue de la responsabilité juridique dans le cadre du harcèlement. C'est la question si la réglementation juridique incluse dans l'article $94^{3}$ du Code de travail a le caractère total qui est devenue le point de départ pour les réflexions engagées. L'analyse faite dans ce domaine a permis de définir le rôle du règlement du Code civil en matière du dédommagement et de la récompense pour le harcèlement professionnel. Dans le présent article, on a commenté aussi les amendements les plus récents de l'article $94^{3} \S 4$ du Code de travail, qui ont été apportés au Code de travail par la Loi du 16 mai 2019 sur le changement de la loi du Code de travail et de quelques autres 
lois (Journal officiel 2019 position 1043). Les réflexions menées sont devenues la base pour formuler la proposition de lege ferenda.

Mots clés: harcèlement professionnel, dédommagement pour le harcèlement, récompense pour le harcèlement, responsabilité juridique, responsabilité civile, biens personnels de l'employé 